Ecquid Novi

ISSN 0256-0054

2003 24(1):37-54

E. North \& S. Millard

\title{
Children and race in South African magazine advertising: Pre- and post- apartheid
}

\begin{abstract}
This article reviews how South African marketers portray children in magazine advertisements in two very distinct periods in the country's history, namely before and after the ANC government came into power in 1994. A longitudinal study (over a 17 -year period) was conducted to determine the incidence, and how marketers in the new South Africa depict children of different races in full page magazine advertisements. The relevance of the findings for South African marketers is highlighted and suggestions for further research are proposed.
\end{abstract}

Hierdie artikel gee ' $n$ oorsig van die gebruik van kindermodelle in tydskrifreklame vóór en na die ANC-regering in 1994 aan bewind gekom het. 'n Longitudinale studie is oor ' $n$ 17-jaar tydperk onderneem om onder meer vas te stel wat die voorkomssyfers is, asook die wyse waarop bemarkers kinders van verskillende rasse in volblad-tydskrifadvertensies uitbeeld. Die relevansie van die studie vir Suid Afrikaanse bemarkers word uitgelig, en voorstelle vir toekomstige navorsing word gemaak.

Key words: Advertising, children, content analysis, magazines, marketing, mixed-race advertisements, South Africa.

\footnotetext{
*Dr Ernest North [ejnorth@hakuna.up.ac.za] is associate professor in the Department of Marketing and Communication Management, University of Pretoria, Lynnwood Road, Pretoria, 0002, South Africa. Tel: +27 (12) 420 3418; Fax: +27 (12) 362 5085; and Salomon Millard [smillard@hakuna.up.ac.za] is senior lecturer in the Department of Statistics, University of Pretoria, Lynnwood Road, Pretoria,0002, South Africa. Tel: +27 (12) 420 3560; Fax: +27 (12) 3625085.
} 


\section{Introduction}

The issue of race and culture in advertising has long been a sensitive topic in many countries of the world. A colour poster distributed to schools in Chicago by a communications group, features a Norman Rockwell-style image of the multicultural Chicago Children's Choir, with the headline: 'Well, now you know at least one place in America where the races are in harmony.' (Advertising Age, 1996). A wide variety of topics have been addressed in this field over the last few decades (Polley \& Callagher, 1990; Alden, Hoyer \& Lee, 1993; Callait \& Mueller, 1996). Yates (1996) reports that mixed-race advertising is 'clearly a big deal' in the United States. Colgate Palm-Olive Co. demanded that an allegedly racist Australian television commercial for sunscreen be pulled of the air (Martin, 1996). In London, Davies (1996) urged advertisers to be sensitive when it comes to racial stereotyping and multicultural representation in advertising. Content analysts have also conducted extensive research in this field. The latter focussed amongst others on the following: the portrayal of African, Hispanic, and Asian Americans in magazine advertising (Taylor, Lee \& Stern, 1995); the portrayal of blacks in Brazilian and US television advertising (Reinart \& Zaharopoulos, 1996); comparing the portrayal of women in black and white magazines (Fears, 1996); and an analysis of sole male images in male-audience magazines (Kolbe \& Albanese, 1996).

A number of studies and articles report on the use of children as models in advertisements. Smith (1994) conducted content analysis to determine how gender differences are portrayed in children's advertising. Alexander (1994) and Viser (1997) studied the changing image of children in magazine advertisements. Viser's study focussed on the images of children in American magazine advertising between 1940 and 1950. Because of the changing economic conditions and socio-cultural perceptions of children in the postWWII USA, one of the hypotheses stated that measures of general emotions will indicate a happier, more exited ad child in the post-war period compared to the pre-war period. The results largely confirmed this hypothesis. Concerns are also raised as to the way children are sexualised and exploited as models in advertisements (Fields, 1999 and Novel, 2000). The literature study in this field concluded that very few studies looked exclusively at cultural or racial aspects in the use of children in advertising or advertising directed at children. In the United States, however, Seiter (1993:43) postulates that in discerning the differences between black and white child models in advertising marketers are ' ...in fact promoting a type of racial stigmatism rather than a celebration of diversity...' 
In the South African context, a limited number of studies investigated the marketing implications of race and/or cultural aspects in advertising. A recent study by Cassim \& Monteiro (2001) gives a picture of the image of blacks in television advertising in the mid-1990s. Only one study has thus far been executed to determine how marketers approach the issue of race or culture when it comes to the portrayal of children in advertising. A content analysis of the portrayal of children in television advertisements, as well as focus groups with children and personal interviews with advertising agencies were conducted (North, 1987).

This article reviews how marketers in South Africa portray children in magazine advertisements in two very distinct periods in the country's history, namely before and after the new government of President Nelson Mandela came to power in 1994. An empirical study was conducted to determine how marketers in the 'new South Africa' approach racial issues in advertising and in particular how children of different races are depicted in full-page magazine advertisements.

The main research questions may be summarized as follows:

- Do marketers make more use of children in magazine advertisements after 1994 compared to the apartheid era?

- $\quad$ Are child models portrayed in specific roles in the advertisements, and if so, do marketers have preferences in this regard?

- Is there a higher incidence of race-mixed children's advertisements after 1994 compared to the earlier years?

- To what extent do the incidence of race-mixed advertisements in weekly consumer magazines who target black readers differ from magazines who target white readers?

- $\quad$ Do the roles children portray in race-mixed advertisements appearing in weekly magazines who cater for black readers, correlate with the roles in magazines who cater for white readers?

\section{Historical context}

The South African population is characterized by a large degree of heterogeneity and multiculturalism. The population (approximately 38 million) consists of four major race groups, namely black people $(29 \mathrm{~m}$.), white people $(5 \mathrm{~m}$.), so-called coloured people (3m.), and people from Asian origin ( $1 \mathrm{~m}$.$) .$ The Constitution makes provision for eleven official languages, namely English, Afrikaans and nine African languages. Obviously, the race/cultural 
issue in South Africa is a very sensitive one. Phrases such as 'equal opportunities for all' and 'non-discriminatory practices' are common. Although most of the practices of the apartheid-era (e.g. 'whites-only' schools, and the lack of housing, medical and transport facilities for black people) have been removed, many black South Africans (including children) still suffer from the legacies of apartheid. In the advertising industry, for example, not one single advertising agency at present is totally black-owned. Almost all of the 153 registered agencies are still white-owned. Recently, mergers between a few black owned and white agencies took place (Association of Advertising Agencies, 2000).

The advancement of a better life and future for children in South Africa is a matter of great concern for the present government. In his inaugural address as the new State President of South Africa, President Nelson Mandela stunned the whole world when he quoted from an Afrikaans poem by a well-known Afrikaans poet, Ingrid Jonker. The title of the poem, 'Die kind' (The child), perhaps gives some indication of how important children are to Mandela and the new ANC government. The focus on the upliftment of especially black children is further illustrated by the foundation of the Nelson Mandela Children's Fund. The depiction of black children in appropriate advertisements can surely enhance this worthy cause.

The dramatic changes, which have recently taken place in South Africa, bring with them many new marketing opportunities. The redistribution of income and rapid westernisation of black South Africans is of special interest to South African marketers. The question arises whether marketers are taking cognisance of this change in the social environment, whether it is reflected in their advertising strategies, and to what extent do they realize that the youth market is a segment that cannot be ignored. Furthermore, the changing social climate also reveals the relationship between advertising strategy and the environment. Marketers in South Africa are challenged to adapt their marketing and advertising strategies to fit in with the new environment brought about by post-apartheid changes. The limited number of appraisals of children and race in advertising, and the relevance of this topic for South African advertisers provided the inspiration for this research.

\section{Child models in commercials}

Although advertising has become an institutionalised part of our economic and social system, certain areas within advertising arouse much emotion and controversy. According to Kinsey (1987) '...the use of children is one of these hotbeds...' 
The use of children as models in advertising is believed to be a very effective method advertisers apply to communicate with parents and other children. The child actor in the advertisement is used as a substitute communicator to convey the advertising message to potential consumers. In many instances children figure as symbols in the advertisement to attract the attention of both adults and other children, to lend a specific meaning to the advertising message, and to create a certain mood in the advertisement. Children are particularly useful as a vehicle to create emotional appeals in commercials. They are more credible because of their innocence, and on the societal level they can be used to transmit positive values from one generation to another. It can be expected that a child will identify more easily with a child model depicted in a social situation than with an adult.

However, depicting and using children in advertisements inherently poses its own set of problems and challenges to marketers. 'The increasingly popular trend of featuring children in commercials that advertise products primarily for an adult market is particularly fraught with controversy' (Judin, 1997:15). According to Solomon (1996) advertising to children can be regarded as an 'ethical minefield'. Advertising to children (and using children in commercials) has been a major focus of public debate and concern in many countries over the years. Marketers who wish to feature children in advertisements to create effective messages that will attract the attention of potential customers should be sensitive to ethical and cultural issues. Regulatory conditions in various countries also restrict advertisers in their decisions to portray children in commercials. A literature study on the regulatory measures of South Africa and some other major countries revealed no specific references to cultural or race issues (when children are depicted in advertisements). The regulations focus mainly on the safety and general well being of the child. A few examples follow next.

A section of the new advertising law in China applies particular restrictions to children's products. Those producing pharmaceutical products cannot show children in a commercial, even if the product is for children (Johnstone, 1996). In the United States virtually every advertising practice comes under the jurisdiction of the Federal Trade Commission (Bovée et al., 1995) Groups such as ACT (Action for Children's Television) and CARU (Children's Advertising Review Unit) have been particularly active in the field of advertising to children. Some objectives of CARU are to monitor children's advertising for truth and accuracy, and to promote research into children's advertising. A major issue is whether advertising results in undesirable socialisation of children. The broader issues, particularly associated with toys and games that involve violence, are whether advertising of such 
games, or the games themselves (showing the child playing with the game), should be disallowed. According to Bradley (1995:664) the use of children in commercials in Europe and surrounding countries is either hamstrung, as advertisers see it, or regulated, as the governments concerned view it. For example, in Finland, child actors may not speak or sing the name of a product in commercials, and munching sweeties are out of order in the Netherlands.

In Sweden no child may be depicted playing with 'war toys', and advertisements may not show the price of toys. And in France, anyone under 16 is banned from enunciating a product name in an advertisement; and they can only introduce a product in a commercial when there exists a direct link between the product and child usage when shown together with adults. The topic of children and advertising was recently discussed in Brussels where reference was made to a Europe-wide study on parental concerns in this regard. The study found that advertising was not a major factor influencing their children and that parents had very few concerns about its effects. (Ad Business, 2000).

In South Africa the ASA (Advertising Standards Authority of South Africa) (1996) regulates the control of advertising to children. When portraying children, the following are examples of rules or guidelines relating to safety: They should not appear to be unattended in street scenes unless they are obviously old enough to be responsible for their own safety, and they should not be seen leaning dangerously out of windows or over bridges, or climbing dangerous cliffs.

The depiction of children in magazine advertisements is a popular method advertisers employ to convey their marketing messages to their target audiences. In the United States a number of magazines target children and the elusive teenage market. Examples are Seventeen and Teen People (a junior version of the popular People magazine). According to Bounds (1998), advertisers have flocked to this magazine who carried nearly a thousand pages of advertising in 1999. Compared to many other countries, advertisers in South Africa presently have a limited choice when it comes to selecting a specialised magazine in which their advertising messages can be conveyed to children. As far as could be established, only one magazine targets children in South Africa, namely Career Guide (aimed at pupils between 14 and 16 years old). The publication contains information on careers, study opportunities in Higher Education, as well as advertisements applicable to children (Nasser, 1997). Advertisers can, however, choose from quite a wide range of consumer magazines in which child actors can be used in advertisements. 


\section{Method}

\section{Sample}

The Audit Bureau of Circulations of South Africa Limited served as basis for the sampling procedure. A non-probability sample of consumer magazines with circulation figures of 100000 or more provided the research instrument for the study. All the full-page advertisements of nine consumer magazines served as the sample frame for the study. A total of 6844 advertisements (total number of full page advertisements in the magazines) were eventually included in the sample. A content analysis of the advertisements in which child actors are portrayed was conducted over 4 three-month periods in 1983, 1987, 1997 and 2000. The focus of the latter study was to compare the portrayal of children in mixed-race advertisements in two magazines that targets white and black readers separately. These magazines were also included in the sample for the earlier studies. The same nine magazines were therefore studied in the four surveys. In total 83 editions of the nine magazines (three weekly, three bi-weekly and three monthly magazines) were used for the purpose of analysis. Four of the magazines cater for the Afrikaans community, three for the English speaking readers and two mainly for the black community.

\section{Categories}

Berelson (1971) and Bush et al. (1983) emphasise the fact that a content analysis is as good as the exact description of the categories. In this study the way children are portrayed in the magazine advertisements constitute the categories. According to Millum (1975) the illustration in a magazine advertisement consists of four elements, namely, the model, the product, the background, and the supporting elements. These elements constituted the criteria according to which the categories (or the roles children play in the advertisements) could be described. The following categories were identified:

- The child acts as a social being in the advertisement (interacting, communicating, playing or being with members of his/her family or with friends or other people).

- $\quad$ The child is depicted as a scholar in the advertisement.

- When the child is participating or wearing suitable sports clothes 
he/she is a participant in sport.

- $\quad$ The child plays the role of an animal lover.

- The child is portrayed as a consumer of the product.

- In some cases the child appears merely as part of the background in the advertisement.

- $\quad$ Finally, children also act as models in testimonial advertisements (being very prominent in the illustration, but not consuming the product).

The categories described above are all mutually exclusive. The description of the categories explicitly stated that the main activity or the focus of the child in the illustration determined the category. For example, a child at school who is playing with his friends during lunch break was classified as a social being and not a scholar.

\section{Coding sheet}

To record the data a coding sheet was designed on which all the relevant data was noted under the specific columns. The coding sheet used by the judge(s) contained specific guidelines that provided a detailed and comprehensive examination of the roles children portray in the illustrations. For coding purposes the age groups of the children were divided into three categories, namely babies and toddlers, young children in primary school and teenagers in secondary school. As a quantitative content analysis was conducted in this study, the results of the survey were put down in numerical and percentage terms. The information was classified under three main sections, namely:

- Information regarding the test unit (full-page advertisements);

- Information regarding the units of observation (the illustrations); and

- Information regarding the coding unit (the child portrayed in the illustration).

The same coding sheet was used in all the studies. A clear limitation of the study is the fact that the researcher did the coding for the first three periods (1983-1997), whereas two post-graduate Marketing students coded the information for the 2000 analysis. 


\section{Results}

The results of the analyses will be presented in two sections, namely for the 1983-1997 period, and for the 2000 study. The following focus areas will be discussed for the 1983-1997 study:

- $\quad$ The frequency of the portrayal of children in the advertisements;

- The various roles children portray in the advertisements;

- $\quad$ Race of models in commercials.

\section{The 1983-1997 studies}

Details of the frequency of the portrayal of children in magazine advertisements before and after 1994 are given in Table 1.

\section{Table 1. Frequency of the portrayal of children in magazine advertisements (1983-1997)}

\begin{tabular}{|l|l|l|l|}
\hline $\begin{array}{l}\text { Child models in illustra- } \\
\text { tions }\end{array}$ & $\begin{array}{l}1983 \\
(\mathrm{n}=2163), \%\end{array}$ & $\begin{array}{l}1987 \\
(\mathrm{n}=1622), \%\end{array}$ & $\begin{array}{l}1997 \\
(\mathrm{n}=1348), \%\end{array}$ \\
\hline $\begin{array}{l}\text { Advertisements portraying } \\
\text { children in the illustration } \\
\begin{array}{l}\text { Advertisements without } \\
\text { children in the illustration }\end{array}\end{array}$ & 11,00 & 10,60 & 16,61 \\
\hline
\end{tabular}

$\mathrm{n}=$ number of advertisements studied

Table 1 shows an increase in the frequency of the portrayal of children from the first two periods to the third (post-apartheid) period (RQ1). Against the background of the fact that the growth in the recorded birth rate from 1991 to 1995 was 33\% (Central Statistical Services, 1997), the increase of approximately $50 \%$ is quite significant. The z-test for proportions indicated that 1997 is positively associated with the portrayal of children in magazine advertisements $(\mathrm{z}=-4.74 ; \mathrm{p}<.001)$. It is assumed that marketers probably believe that the portrayal of youthfulness can increase the effectiveness of the advertisement. The findings of a study by Wiles et al. (1996), in which the similarities and differences between the values portrayed in magazine advertising in the US and Sweden were examined, indicate that advertising more often portrays youthfulness. A majority of the models in the US maga- 
zines (more than 40\%) appeared to be 16 to 30 years of age. Almost 21\% were 0 to 15 years of age. Marketers also seem to use children in advertising because they can be regarded as consumers in own right. They have unprecedented purchasing power and also exert a great influence on household buying decisions (Ward \& Wackman, 1972). In South Africa there are approximately 12,9 million school going children of which $35 \%$ in secondary school commands a disposable income of R4 billion/year (Mulrooney, 1999). According to Koenderman (2001) children (of all ages) spend R4.5 billion/year in South Africa and influence the spending of another R20 billion/year including the purchases of items such as television sets and cars.

The analysis revealed that child actors portray seven different roles (RQ2) in the advertisements, and that marketers prefer to portray them more frequently in certain roles as recorded in Table 2.

\section{Table 2. Roles portrayed by children in magazine advertise- ments (1983-1997)}

\begin{tabular}{|l|l|l|l|}
\hline $\begin{array}{l}\text { Roles portrayed by } \\
\text { children }\end{array}$ & $\begin{array}{l}\mathbf{1 9 8 3} \\
(\mathbf{n = 2 3 8}), \boldsymbol{\%}\end{array}$ & $\begin{array}{l}\mathbf{1 9 8 7} \\
(\mathbf{n = 1 7 2}), \boldsymbol{\%}\end{array}$ & $\begin{array}{l}\mathbf{1 9 9 7} \\
(\mathbf{n = 2 2 4}), \boldsymbol{\%}\end{array}$ \\
\hline $\begin{array}{l}\text { Social context: } \\
\text { (Family) }\end{array}$ & 43 & 52 & 34 \\
(Peer group) & $(35)$ & $(36)$ & $(29)$ \\
(Other) & $(8)$ & $(14)$ & $(5)$ \\
Scholar & $(0)$ & $(2)$ & $(0)$ \\
Partaker in sport & 4 & 0,5 & 1 \\
Animal lover & 2 & 0,5 & 4 \\
Testimonial & 3 & 1 & 2 \\
Consumer & 3 & 19 & 29 \\
Background & 34 & 24 & 27 \\
\hline
\end{tabular}

$\mathrm{n}=$ number of advertisements in each sample

Marketers portrayed child models as social beings in most of the cases studied between 1983 and 1997 (RQ2). Child actors appeared mostly with members of the family in the three years mentioned above. Although a significant decrease in the role of a social being occurred from 1987 (52\%) to 1997 (34\%), $(\mathrm{z}=3.55 ; \mathrm{p}<.001)$, acting as social beings is also the role marketers seem to prefer when portraying children of more than one race in the same advertisement (see Table 5). Acting as consumers of the product is the role 
in which children are portrayed second most. For all three years children were not portrayed very frequently in the roles of animal lovers (no black children appeared in these advertisements), scholars and partakers in sporting activities. Table 2 indicates that the depiction of children in sporting roles increased from $0.5 \%$ in 1987 to $4 \%$ in 1997 . It must be noted, however, that black children acted as partakers in sport in less than $10 \%$ of these cases. It is not clear why marketers of sporting goods and equipment make much more use of black children in these advertisements. Almost all the major sporting bodies in South Africa became professional over the last few years. Much is also being done to promote sport in the disadvantaged communities and to encourage young black people to participate in sport. Sponsorships and development programs for black children are common practices in South Africa nowadays. Future market research on culture and sport may possibly supply marketers with valuable information to underpin strategies for the marketing of sporting goods to athletes in diverse race and cultural groups.

Marketing to this new generation and including children of all races in advertisements (RQ3) is expected to be part of the advertising strategies of marketers in the new South Africa. Is this the case or not? The answer can (at least partially) be found in Table 3 .

\section{Table 3. Race of child models in magazine advertisements (1983-1997)}

\begin{tabular}{|l|l|l|l|}
\hline Race of models & $\begin{array}{l}\mathbf{1 9 8 3} \\
(\mathbf{n = 2 3 8}), \boldsymbol{\%}\end{array}$ & $\begin{array}{l}\mathbf{1 9 8 7} \\
(\mathbf{n = 1 7 2}), \%\end{array}$ & $\begin{array}{l}\mathbf{1 9 9 7} \\
(\mathbf{n = 2 2 4}), \boldsymbol{\%}\end{array}$ \\
\hline $\begin{array}{l}\text { Advertisements portraying chil- } \\
\text { dren of different races in the illus- }\end{array}$ & 5,04 & 1,16 & 10,71 \\
$\begin{array}{l}\text { tration } \\
\text { Child models of one race in the } \\
\text { illustration }\end{array}$ & 94,96 & 98,84 & 89,29 \\
\hline
\end{tabular}

$\mathrm{n}=$ number of advertisements portraying children

The tide has certainly turned! The results indicate that a noticeable increase in the portrayal of children of different races has taken place in the postapartheid period (almost 11\% in 1997) compared to the apartheid era (5\% in 1983 and $1 \%$ in 1987). The z-test for proportions confirmed that there was a higher incidence of advertisements in 1997 portraying children of different races in the same advertisement $(\mathrm{z}=-4.30 ; \mathrm{p}<.001)$. These figures firstly 
confirm the fact that the South African community is in a process of radical change, and secondly they probably indicate that marketers are beginning to realize that their advertising messages should reflect the true nature of the new South Africa. However, taking cognisance of the fact that black people constitute 76\% (1996 statistics) of the total South African population, the $89 \%$ portrayal of white models only, can be seen as a disproportionate use of white children in advertising. Although the Wiles study (1996) did not look exclusively at children, the results also indicate an imbalance in the representation of race in the advertisements.

\section{The 2000 study}

Two of the nine magazines included in the study, namely Drum and Bona, cater mainly for black readers. The main aim of the 2000 study was to determine if (and to what extent) there are differences in the way marketers portray children of both races in the same advertisements in Drum (a weekly publication aimed at mainly black readers), compared to those depicted in You (a weekly publication aimed at mainly white readers). Both these two magazines can be classified as general consumer magazines that cater for a wide variety of readers. The following aspects will be highlighted in this section:

- Comparing the demographic details of the children depicted in the race-mixed advertisements in the two magazines.

- Determining whether there is differences in respect of the roles children portray in race-mixed advertisements in the abovementioned magazines.

As mentioned before, a total of 6844 advertisements were included in the sample for this study. For the 2000 study a total of 1711 advertisements were analysed. Two hundred and seventy four of the advertisements that portrayed children appeared in You, while 126 full-page advertisements in Drum depicted children in the advertisement. The answer to research question 4 (to what extent do the incidence of race-mixed advertisements differ in weekly magazines who target black and white readers separately) can be found in Table 4. 


\section{Table 4. Demographic details of child models in race-mixed advertisements in weekly magazines (2000)}

\begin{tabular}{|l|l|l|}
\hline Magazine/Criteria & You (\%) & Drum (\%) \\
\hline Frequency of models & $(\mathrm{n}=274)$ & $(\mathrm{n}=126)$ \\
in advertisements & 12 & 22 \\
\hline Age: & $(\mathrm{n}=34)$ & $(\mathrm{n}=28)$ \\
Babies/toddlers & 29 & 36 \\
Young children & 71 & 64 \\
Teenagers/Mixed & 0 & 0 \\
\hline Gender: & $(\mathrm{n}=34)$ & $(\mathrm{n}=28)$ \\
Boy & 29 & 7 \\
Girl & 35 & 29 \\
Mixed & 24 & 43 \\
Unknown & 12 & 21 \\
\hline Race-mixed advertise- & $(\mathrm{n}=34)$ & $(\mathrm{n}=28)$ \\
ments & 29 & 0 \\
\hline
\end{tabular}

$\mathrm{n}=$ number of advertisements in sample

A comparison between the two weekly magazines who cater for separate target audiences indicate that, although much less full page advertisements portraying children appear in Drum (126 vs. 274), the use of children in the advertisements depicted in Drum (22\%) are almost double than the 12 per cent in You ( $\mathrm{z}=-2.43 ; \mathrm{p}=.007)$. In both magazines younger children (aged 612 ) are mostly used. It is surprising to note that not one advertisement in the two magazines depicted teenagers over the three-month period. In 43 per cent of the cases in Drum, advertisers preferred to use mixed-gender groups in the advertisements. A surprising result is that Drum did not contain any advertisements in which children of both races are depicted in the same ad, whereas almost one-third race-mixed advertisements appeared in You. In these instances it must be noted, however, that white models are more prominent in the illustrations than black children.

The results of the analysis to determine the roles child actors portray in race-mixed advertisements in the two weekly magazines (Table 5), correlate to a large extent with the findings of the previous 1983-1997 studies. Advertisers prefer to depict child models in social settings, as consumers of advertised products, and acting as testimonials in the advertisements. Table 5 indicates that no advertisements in the magazines depicted children as scholars or as partakers in sport. Also, not one advertisement in Drum por- 
trayed a black child in the role of an animal lover. Six percent of the models in You acted in the role of animal lovers. And 6\% also appeared in the advertisements as part of the background, compared to 0\% in Drum. Notably more models in You portray the role of a social being (47\%) compared to 35\% in Drum (RQ5).

\section{Table 5. Roles portrayed by children in race-mixed advertise- ments of two weekly magazines (2000)}

\begin{tabular}{|c|c|c|}
\hline $\begin{array}{l}\text { Magazines/Roles por- } \\
\text { trayed by children in } \\
\text { race-mixed } \\
\text { ments* }\end{array}$ & $\begin{array}{l}\text { You }(n=34) \\
\%\end{array}$ & $\begin{array}{l}\text { Drum }(n=28) \\
\%\end{array}$ \\
\hline $\begin{array}{l}\text { Social context: } \\
\text { (Family) } \\
\text { (Peer group) } \\
\text { Scholar } \\
\text { Partaker in sport } \\
\text { Animal lover } \\
\text { Testimonial } \\
\text { Consumer } \\
\text { Part of background/sup- } \\
\text { porting element }\end{array}$ & $\begin{array}{l}47 \\
(35) \\
(12) \\
0 \\
0 \\
6 \\
23 \\
18 \\
6\end{array}$ & $\begin{array}{l}35 \\
(21) \\
(14) \\
0 \\
0 \\
0 \\
36 \\
29 \\
0\end{array}$ \\
\hline
\end{tabular}

$\mathrm{n}=$ number of advertisements in each sample

$*$ The intercoder reliability was a very acceptable $96.15 \%$. Literature indicate that intercoder reliability of $85 \%$ or above is acceptable (Caillat \& Mueller, 1996; Viser, 1997).

\section{Discussion and conclusions}

A significant increase in the portrayal of children of different races in the same advertisement was recorded in the post-apartheid period (11\% in 1997, compared to the apartheid era of 5\% in 1983 and a mere 1\% in 1987). However, although this increase is a step in the right direction, the overall findings of the study suggest that the advertising strategies of many marketers in South Africa still do not reflect the real changes, which are taking place in the country. The discretionary income of black people has increased considerably over the past few years, which opens up many opportunities for marketers. Not only can adults be targeted, but marketing efforts can also be di- 
rected to get the attention of the new young generation by building brand loyalty among the adult consumers of tomorrow. By using children of a variety of races in advertisements marketers can convey their advertising messages to various target markets. These kinds of illustrations can also serve to influence black consumers to adopt a Western lifestyle, which would encourage the consumption of products such as typically Western clothing and vehicles. Marketers could also explore more opportunities in future that can enhance the effectiveness of their communication strategies. Children could for example be used in advertisements to portray the role of music lovers, partakers in sport, or taking part in entrepreneurial activities. And also in situations where they acquire skills to become responsible citizens and skilful consumers.

On average, South African marketers rarely use teenagers in the advertisements. For the purpose of the research, the age of each of the child models in the advertisements was classified under three broad categories, namely: a pre-school phase, younger children in the primary school, and teenagers. The results of the studies indicate that marketers mostly use preschool and younger children as actors in the advertisements. The type of product advertised (e.g. personal care products) and the target audience (mothers) probably explain why most advertisements portray younger children. The use of teenagers as models for the three periods was a somewhat disappointing 27\% (1983), 24\% (1987), and 11\% (1997). Not one teenager was depicted in the weekly magazines included in the 2000 study. They prefer to use pre-school (especially babies) and younger children as actors in the advertisements. The reason why they do not make more use of teenagers (for example to promote sporting goods) is unknown and is a topic for further research.

The following interesting observations were made during the postapartheid (2000) analysis of the advertisements in which children of more than one race are portrayed:

- $\quad$ In the majority of cases where children of different races are depicted in the same advertisement, they interact socially by laughing, singing or playing together. This was not the case in the 1983 and 1987 studies.

- $\quad$ Almost one-third of the advertisements in the weekly magazine You (targeting white readers) featured children of various races in the advertisements. Not one race-mixed ad appeared in Drum (research question 4).

- $\quad$ Not one mixed-race ad portrayed children in the roles of scholars or 
as participants in sport. Politicians and the broad public realise what the value of sport is to normalise relationships in the post-apartheid South Africa. Marketers of sporting goods could benefit when children of different races are depicted in the same advertisement.

- $\quad$ Children of both genders and both races (e.g. a black girl and a white boy) are depicted in the same advertisement. The social implications of these kinds of advertisements can be far reaching.

- A very surprising result was the fact that while marketers increasingly use black child models in traditionally 'white' consumer magazines, using white models in a 'black' magazine, though, is the exception to the rule.

- In a few instances marketers made use of drawings instead of photographs. In some of these illustrations the race of the child model was difficult to determine. In these cases it is believed that the marketer's intention could have been to create a 'melting pot' that will reflect the true nature of the new South Africa. Further research will be necessary to confirm this hypothesis.

- $\quad$ Three product categories, namely products for personal care (e.g. toothpaste, medicine, and shampoo), clothing, and food represented almost $82 \%$ of the products advertised in the mixed-race advertisements.

Although the results are based on an analysis of one medium only, it is believed that they are representative of other mediums of advertising, for example television advertising. It is recommended that a repeat study of the 1987 study (in which the use of children in television advertising was conducted) be done to test the above-mentioned hypothesis. Further research is also needed to take a look at children's advertising on the Internet. This study mainly focussed on the portrayal of children of different races in the same advertisement. No explanations are given as to why marketers use children of different races in the same advertisement or, for example, why black children are not depicted as animal lovers. Future research perhaps in the form of focus groups or personal interviews with advertisers should supply more answers.

\section{References}

Advertising Age, 1996.

Ad Business, 2000. EAAA Update.

Association of Advertising Agencies, 2000. Personal telephonic interview conducted on 
17 July 2001.

Alden, D.L., Hoyer, W. \& Lee, C. 1993. Identifying global and culture-specific dimensions of humour in advertising: A multinational analysis. Journal of Marketing, 57(2):64-75.

Alexander, V.D. 1994. The image of children in magazine advertisements from 1905 to 1990. Communication Research, 21(6): 742-779.

Berelson, B. 1971. Content analysis in communication research. New York: Hafner Publishing.

Bounds, W. 1998. Teen-magazine boom. Beauty, fashion, stars and sex. The Wall Street Journal, December: 4.

Bovee, C.L., Till, J.V., Dovel, G.P. \& Wood, M.B. 1995. Advertising excellence. New York: McGraw-Hill.

Bradley, F. 1995. Marketing management. providing communicating and delivering value. Englewood Cliffs: NJ: Prentice-Hall.

Bush, A.J., Hair, J.F. \& Busch, R.R. 1983. A content analysis of animation in television advertising, Journal of Advertising, (4):20-26, Industrial Marketing Management, July: 145-149.

Caillat, Z. \& Mueller, B. 1996. Observations. The influence of culture on American and British advertising. An exploratory comparison of beer advertising. Journal of Advertising Research, 36(3):79-88.

Cassim, S. \& Monteiro, M. 2001. Black role portrayals in South African television advertising. Ecquid Novi, 22(1):106-123.

Central Statistical Services 1997. PO 35 Pretoria.

Davies, J. 1996. Advertising's last taboos. Campaign-London, March: 30-31.

Fears, L. 1995. Comparing portrayal of women in black and white magazines. Conference Proceedings of the Association for Education in Journalism and Mass Communication, August: 9-12

Fields, S. 1999. Calvin Klein advertisements again use kids and sex to sell. Philadelphia Business Journal, 18(4):47-48.

Johnstone, H. 1996. 'Little emperors' call the shots'. Asian Business, September: 67-70.

Judin, M. 1997. 'Children' spells 'C' for cash. The S.A. Journal of Marketing \& Sales, 3(6): 15.

Kinsey, J. 1987. The use of children in advertising and the impact of advertising aimed at children. International Journal of Advertising, 6(2):169-175.

Koenderman, T. 2001. Marketing: Catch 'em young. Financial Mail, June: 85.

Martin, G.L. 1996. Colgate demands TV ad not to be run in contests. Advertising Age, May: 42.

Millum, T. 1975. Images of woman. Advertising in women's magazines. London: Chatto $\&$ Windus.

Mulrooney, B. 1999. Today's kids, today's mega spenders. Marketing Mix, September: 26-33.

Nasser, D. 1997. The medium for school children. Marketplace, April: 18.

Novel, A. 2000. Jakarta Post, February: 27.

North, E.J. 1987. Multistapnavorsing oor kinders in reklame (Multi-step research into the use of children in advertising). Unpublished D.Com dissertation, University of South Africa: Pretoria. 
Polley, R. \& Callagher, K. 1990. Advertising and cultural values. International Journal of Advertising, (9):359-372.

Reinart, V. \& Zaharopoulos, T. 1995. The portrayal of blacks in television advertising: A comparison of Brazilian and US television. Conference Proceedings of the Association for Education in Journalism and Mass Communication, August: 9-12.

Seiter, E. 1993. Sold Separately: Children and parents in consumer culture. New Brunswick: Rutgers University Press.

Smith, L. 1994. A content analysis of gender differences in children's advertising. Journal of Broadcasting and Electronic Media, 38:323-327.

Solomon, M.R. 1996. Consumer Behaviour 3rd edition). Englewood Cliffs, NJ: PrenticeHall.

Taylor, C., Lee, J. \& Stern, B. 1995. Portrayals of African, Hispanic, and Asian Americans in magazine advertising. American Behavioural Scientist, 38(4):608-621.

The Advertising Standards Authority of South Africa. 1996. Regulations for the advertising industry. Johannesburg: Butterworths.

Viser, V. 1997. Mode of address, emotion and stylistics. Images of children in American magazine advertising (1940-1950). Communication Research, 24(1):83-101.

Ward, S. \& Wackman, D.B. 1972. Children's purchase influence attempts and parental yielding. Journal of Marketing Research, 9(3):316-319.

Wiles, C.R., Wiles, J.A. \& Tjernland, A. 1996. The ideology of advertising: The United States and Sweden. Journal of Advertising Research, 36(3):57-66.

Yates, K. 1996. Ikea ad raises the race issue. Campaign London. 